REFLEKSI HUKUM

Jurnal Imu Hukum
p-ISSN 2541-4984 | e-ISSN 2541-5417

Volume 5 Nomor 2, April 2021, Halaman 145-160

Open access at: http:// ejournal.uksw.edu/refleksihukum

Penerbit: Fakultas Hukum Universitas Kristen Satya Wacana

\title{
PERLINDUNGAN HUKUM TENAGA KERJA KONTRAK DAN OUTSOURCING, SERTA PROBLEMATIKA IMPLEMENTASINYA
}

\section{Tri Budiyono}

Fakultas Hukum Universitas Kristen Satya Wacana | trbuuksw61@yahoo.com

\author{
A R T I C L E I N F O \\ Article history: \\ Received \\ 4 September 2020 \\ Revised \\ 19 November 2020 \\ Accepted \\ 15 April 2021
}

Kata-kata Kunci:

Pengusaha;

Buruh;

Perlindungan Hukum;

Mahkamah Konstitusi;

Demi hukum.

Keywords: Employee; Legal Protection; Constitutional Court; for the sake of law.

\begin{abstract}
Abstrak
Hubungan pengusaha dan buruh cenderung diwarnai ketegangan yang bersifat tolak-tarik. Pengusaha memelihara kontinuitas usaha untuk mendapat keuntungan yang optimal, sementara buruh berusaha untuk mendapat upah atau kesejahteraan yang layak. Bentuk perjuangan buruh dilakukan melalui jalur konstitusional, dengan mengajukan judicial review terhadap UU No. 13 Tahun 2003 tentang Ketenagakerjaan. Dengan pendekatan konseptual dan filosofis terhadap bahan hukum putusan MK yang relevan dengan pokok kajian, penelitian ini mengkaji perjuangan buruh untuk mendapat jaminan legal yang lebih berkepastian hukum. Temuan dari hasil penelitian ini adalah: (a) konstatasi hukum "demi hukum" yang seharusnya mampu memberi perlindungan hukum yang kuat, masih menimbulkan multi tafsir yang berujung hilangnya perlindungan hukum yang berkepastian. (b) Mahkamah Konstitusi melalui putusannya, telah meletakkan dasar legalitas yang lebih berkepastian hukum melalui implementasi norma perlindungan buruh secara berjenjang. (c) putusan Mahkamah Konstitusi sekalipun memberi kepastian hukum pada aras normatif, namun masih menyisakan ketidakpastian perlindungan hukum pada aras empirik.
\end{abstract}

\section{Abstract}

The relationship between employers and workers tends to be characterized by a tension between the employers' and workers' interests. While the employers maintain business continuity to obtain optimal advantages, the workers demand to get decent wages or welfare. For example, the laborers have struggled through a constitutional way by submitting a judicial review of Law No. 13 of 2003 concerning Manpower. This research used a conceptual approach and a philosophical approach to observe the relevant legal material in the Constitutional Court's decision to obtain legal guarantees with more legal certainty. In conclusion, this research found that: (a) The phrase 'for the sake of the law' should have granted the laborers more legal protection. However, it still creates multiple interpretations that lead to the loss of certain legal protections. (b) The Constitutional Court, through its decision, has laid the basis of legality with more legal certainty through the implementation of labor protection norms gradually. (c) Even though the Constitutional Court's decision has already provided legal certainty normatively, the uncertainty of legal protection still exists in practices. 


\section{PENDAHULUAN}

Bekerja merupakan hak setiap warga negara Indonesia, yang dijamin dalam konstitusi. ${ }^{1}$ Hak konstitusional ini yang sejatinya juga merupakan hak asasi, hak yang diakui melekat pada diri manusia sejak dia lahir sampai yang bersangkutan meninggal dunia, oleh karena ia adalah semata-mata ciptaan Tuhan. Pasal 28D ayat (1) Undang Undang Dasar Negara Republik Indonesia Tahun 1945 (disingkat UUD' 45) menyatakan: "Setiap orang berhak atas pengakuan, jaminan, perlindungan, dan kepastian hukum yang adil serta perlakuan yang sama di hadapan hukum."2 Pasal 28 D ayat (2) UUD'45 menyatakan: "Setiap orang berhak untuk bekerja serta mendapat imbalan dan perlakuan yang adil dan layak dalam hubungan kerja."3 Pasal-pasal ini, juga menjadi jangkar konstitusionalitas perlindungan hukum terhadap warga negara Indonesia, termasuk di dalamnya adalah pekerja.

Sekalipun bekerja adalah hak-hak asasi manusia dan secara konstitusi telah mendapat perlindungan hukum, namun realitas kehidupan tidak selalu menunjukkan paralelitas diantara keduanya. Dalam tataran empirik, dinamika dan problematika menunjukkan masalah hukum terkait dengan hubungan antara pekerja dan pemberi kerja, ternyata banyak terjadi. ${ }^{4}$ Bahkan hubungan antara pekerja dan pemberi kerja terjadi dinamika tolak-tarik, dan masing-masing pihak acap kali merasa menjadi korban tekanan (politik) kelompok lain. Pekerja acap kali merasa menjadi korban tekanan pemilik modal yang disinyalir berkonspirasi dengan penguasa, sedang pemberi kerja acap kali merasa menjadi korban dari gerakan buruh yang tidak jarang berujung pada anarkisme. ${ }^{5}$

Secara teoritik dapat dipahami bahwa posisi buruh dan pemberi kerja, bersifat asimetris dan diametral (saling berhadap-hadapan). Posisi diametral ini melahirkan lembaga bipartit - yang mempertemukan pekerja dan pemberi kerja - untuk menyelesaikan perselisihan hubungan industrial. Hubungan yang bersifat asimetris dapat diindikasikan antara lain dari 6:

1 Jimly mengemukakan hak asasi manusia dan hak konstitusional warga dalam bidang perekonomian mencakup: (a) hak-hak dan kebebasan atas hak milik (freedom of property), (b) kebebasan dan kesempatan yang sama untuk bekerja (freedom of occupation), dan kebebasan dan kesempatan yang sama untuk dan dalam berusaha. Lihat lebih lanjut Jimly Asshiddiqie, Konstitusi Ekonomi (PT Kompas Media Nusantara Jakarta 2010) 208; Lihat juga, Sudjatmoko, Dialog Indonesia dan Masa Depan (Usaha Offset Surabaya 1992) 95.

$2 \quad$ Pasal 28D ayat (1) Undang-Undang Dasar Negara Republik Indonesia Tahun 1945.

Pasal 28D ayat (2) Undang-Undang Dasar Negara Republik Indonesia Tahun 1945.

Serang yang merupakan salah satu kabupaten industri misalnya, selama tahun 2019 Dinas Tenaga Kerja (Disnakertrans) menangani 97 kasus ketenagakerjaan. Dari jumlah tersebut kasus Perjanjian Kerja Waktu Tertentu (PKWT) paling mendominasi. Tresna Mulyanawati, 'Masalah Ketenagakerjaan Selama 2019, Kasus PKWT Mendominasi' (Kabar Banten, 8 Januari 2020) < https://kabarbanten.pikiran-rakyat.com/serang/pr-59623797/masalah-ketenagakerjaanselama-2019-kasus-pkwt-mendominasi?page $=2>$ diakses 30 April 2020.

5 Muhammad Zuhdan dalam tulisannya berjudul "Perjuangan Gerakan Buruh Tidak Sekedar Upah, Melacak Perkembangan Isu Gerakan Buruh di Indonesia Pasca Reformasi", menyimpulkan bahwa isu gerakan buruh di Indonesia pasca reformasi tidak lagi berkutat pada isu kenaikan upah saja tetapi berkembang progresif ke arah isu-isu politis yang identik dengan gerakan Kiri Baru, mulai dari isu buruh Go Politic, anti neoliberalisme, gender, HAM, demokrasi, kewarganegaraan, kebijakan publik, dan sebagainya. Muhammad Zuhdan, 'Perjuangan Gerakan Buruh Tidak Sekedar Upah, Melacak Perkembangan Isu Gerakan Buruh di Indonesia Pasca Reformasi' (2014) 17 (3) Jurnal Ilmu Sosial dan Ilmu Politik 272.

$6 \quad$ Frans Magnis Suseno menilai persaingan antara kelas pemilik modal dan kelas buruh sejatinya adalah persaingan yang sifatnya objektif, tidak disebabkan kelas buruh iri atau kelas pemilik 
1. Pemberi kerja memiliki posisi tawar yang dominan dan lebih tinggi, sebaliknya buruh berada pada posisi tawar yang lebih rendah.

2. Permintaan tenaga kerja oleh dunia usaha bersifat oligopsoni, sementara dari sisi buruh berada dalam persaingan bebas.

3. Orientasi pengusaha adalah keuntungan yang optimal dan salah satunya dengan menekan biaya (baca: upah buruh), sementara orientasi dari buruh adalah upah/kesejahteraan yang tinggi yang berarti juga meningkatkan komponen biaya yang harus ditanggung oleh perusahaan.

Dalam pandangan Karl Marx, ${ }^{7}$ kondisi ini telah melahirkan kelas-kelas dalam masyarakat, yaitu kelas pemilik modal (baca: kaum feudal) dan kelas buruh (baca: kaum proletar), yang saling berkompetisi. Bahkan, dalam ramalan Karl Marx gesekan kepentingan antar kelas ini akan melahirkan revolusi social. 8 Relasi tolak tarik antara pekerja (baca: buruh) dan pemberi kerja (baca pemilik modal), rasarasanya telah, sedang, dan akan terus mewarnai dinamika hubungan industrial baik secara global, regional, dan juga lokal. Dalam relasi yang bersifat asimetris seperti ini, kompetisi secara alami (diserahkan pada posisi tawar masing-masing pihak) akan melahirkan ketidakadilan, yang lemah (baca: buruh) akan terus menjadi objek eksploitasi kelas yang kuat (baca: pemilik modal). Salah satu solusi yang urgent untuk menjamin keseimbangan adalah melalui kehadiran negara untuk memberikan advokasi pada kelompok yang lemah, antara lain melalui pemberlakuan norma/kaidah yang memberikan perlindungan hukum kepada buruh. Dalam tulisannya berjudul Revolusi Industri Keempat: Akhir dari Buruh di Seluruh Dunia, Teduh G. Alam (et. all) menyimpulkan bahwa dalam 4 (empat) kali revolusi industri, ${ }^{9}$ posisi buruh terus tergerus dan tersisihkan. Dalam posisi yang

modal egois. Frans Magnis Suseno, Pemikiran Karl Marx: Dari Sosialisme Utopis ke Perselisihan Revisionisme (cet. ke-8, Gramedia Pustaka Utama Jakarta 2010) 110-134.

$7 \quad$ Pemikiran Karl Marx bertumpu pada perjuangan kelas, yang beranggapan bahwa pelaku utama dalam masyarakat adalah kelas-kelas social. Mark membedakan masyarakat berdasarkan kelas berdasarkan mode produksi (teknologi dan pembagian kerja). Dalam karya The communist Manifesto Marx mengungkapkan slogan: "The history of all hitherto existing societies is the history of class struggles. Freeman and slave, patrician and plebeian, lord and serf, guild-master and journeyman, in a word, oppressor and oppressed, stood in constant opposition to one another, carried on an interrupted, now hidden, now open fight, a fight that each time ended in a revolutionary reconstruction of society at large, or in the common ruin of the contending classes." Karl Marx dalam Indriaty Ismail dan Muh Zuhaili Kamal Basir, 'Karl Marx dan Perjuangan Kelas' (2012) 1 International Journal of Islamic Thought 27, 29.

8 Kelas bawah (buruh) berkepentingan untuk melawan dan menggulingkan kelas atas. Sebaliknya, kelas atas (pemilik modal) berusaha mempertahankan kekuasaanya. Oleh sebab itu, perubahan sistem sosial hanya bisa dilakukan dengan jalan kekerasan, melalui revolusi. Frans Suseno (n 6)

$9 \quad$ Empat kali revolusi industri meliputi: a. penemuan mesin uap pada abad ke-18, b. penemuan mesin bertenaga listrik dan minyak pada awal abad ke-20, c. Penemuan teknologi informasi yang dilanjutkan pengembangan internet pada pertengahan abad ke-20 (tahun 1960an), dan d. Penemuan artifisial intelligent (kecerdasan buatan) dan penggunaan computer generasi ke-empat (4.0) pada awal abad ke-21. Lihat lebih lanjut, Teduh Gentar Alam, dkk, 'Revolusi Industri Keempat: Akhir dari Buruh di Seluruh Dunia' (2019) 12 (2) Jurnal Hubungan Internasional 229232. Selain tengara 4 (empat) revolusi industri tersebut, dalam dunia ilmu pengetahuan juga dikenal penamaan lain, yaitu Revolusi Industri 1.0, Revolusi Industri 2.0, Revolusi Industri 3,0, dan Ravolusi Industri 4.0. Doni Budi P, 'Sejarah Revolusi Industri1.0 hingga 4.0' (otomasi, 9 Oktober 2018) <https://otomasi.sv.ugm.ac.id/2018/10/09/sejarah-revolusi-industri-1-0hingga-4-0/> diakses 27 April 2020. 
demikian, peningkatan kemampuan manusia merupakan tugas individu dan masyarakat agar dapat bertahan dan berkembang di dunia yang berubah.

Revolusi industri sejatinya telah berpotensi memunculkan krisis keterhubungan antara buruh dan pemilik modal. Diantara sekian banyak titik krusial hubungan industrial yang ada, relasi antara pemberi kerja - buruh yang terikat dengan Perjanjian Kerja Waktu Tertentu (PKWT) dan tenaga alih daya (outsourcing), menarik peneliti untuk dikaji. Dalam relasi yang sifatnya asimetris ini, negara sejatinya telah hadir dengan memberikan perlindungan tenaga kerja berdasarkan PKWT dan alih daya, terutama melalui pengaturan peralihan status hubungan kerja yang bersifat demi hukum. PKWT dan alih daya, menurut UU No. 13 Tahun 2003 demi hukum beralih status menjadi pekerja berdasarkan Perjanjian Kerja Waktu Tidak Tertentu (PKWTT) ${ }^{10}$ atau tenaga kerja outsourcing demi hukum memiliki hubungan kerja dengan perusahaan yang pemberi pekerjaan. ${ }^{11}$ Namun demikian pada tataran empirik peralihan status pekerja yang sifatnya demi hukum tersebut tidak mudah (kalau tidak mau dibaca mustahil) dilaksanakan. Penyebab utamanya adalah, implementasi kaidah tersebut sepenuhnya tergantung pada kesadaran pemberi kerja.

Tulisan ini akan difokuskan pada kajian terhadap kesenjangan antara teks undang-undang dan implementasinya dalam kasus konkrit (empiris). Putusan Mahkamah Konstitusi (MK) No. 7/PUU-XII/2014, Putusan MK No. 96/PUUVII/2013, dan Putusan MK No. 27/PUU-IX/2011 akan menjadi bahan hukum utama dalam penelitian ini. Metode yang dipergunakan untuk mengkaji permasalahan ini adalah metode juridis normatif dengan menekankan pada pendekatan konsep (conceptual approach) dan pendekatan filosofis (philosophical approach). Permasalahan peralihan status PKWT dan tenaga outsourcing yang sifatnya demi hukum akan menjadi fokus kajian dari tiga perspektif, yaitu perspektif pengusaha, buruh dan/atau serikat pekerja, dan hakim MK. Sekalipun studi ini tidak bermaksud membuat generalisasi, tetapi hasil kajiannya dapat dipergunakan untuk memahami hukum secara umum, terutama terhadap relasi antara perlindungan hukum pada aras normatif dan perlindungan hukum pada aras empiris.

\section{PEMBAHASAN}

Phillipus M. Hadjon merumuskan perlindungan hukum sebagai perlindungan akan harkat dan martabat, serta pengakuan terhadap hak-hak asasi manusia yang dimiliki oleh subyek hukum berdasarkan ketentuan hukum dari kesewenangan atau sebagai kumpulan peraturan atau kaidah yang akan dapat melindungi suatu hal dari hal lainnya hak-hak tersebut. ${ }^{2}$ Soerjono Soekanto mengartikan perlindungan hukum sebagai segala upaya pemenuhan hak dan pemberian bantuan untuk memberikan rasa aman kepada saksi dan atau korban, yang dapat diwujudkan dalam bentuk seperti melalui restitusi, kompensasi, pelayanan medis,

Pasal 59 ayat (7) UU No. 13 Tahun 2003 tentang Ketenagakerjaan.

Pasal 65 ayat (8) dan Pasal 66 ayat (4) UU No. 13 Tahun 2003 tentang Ketenagakerjaan.

Phillipus M. Hadjon, Perlindungan Hukum Bagi Rakyat Indonesia, Studi mengenai Prinsip-Prinsip

Penangannya oleh Pengadilan dalam Lingkup Peradilan Umum dan Pembentukan Peradilan Administratif Negara (Bina Ilmu Surabaya 1987) 25. 
dan bantuan hukum. ${ }^{13}$ Bentuk perlindungan hukum dapat berupa kumpulan peraturan atau kaidah, perlindungan hukum juga dapat berupa penegakan peraturan atau kaidah pada kasus konkrit yang bersifat individual.

Perlindungan hukum, selain dapat dipilah menjadi perlindungan hukum preventif dan perlindungan hukum represif, juga dapat dipilah menjadi 2 (dua) aras, yaitu perlindungan hukum pada aras normatif dan perlindungan hukum pada aras empirik. Pada aras normatif, perlindungan hukum dapat ditelusur pada ketersediaan norma atau kaidah pada peraturan perundang-undangan. Apakah peraturan perundang-undangan memberikan rumusan norma yang memberikan kepastian (certainty) apabila terjadi pelanggaran hak untuk memulihkannya. Dari perspektif ini, apabila peraturan perundang-undangan telah memberikan norma pemulihan hak secara memadahi maka secara normatif dapat dikatakan perlindungan hukum telah ada. Permasalahannya adalah, perlindungan hukum secara normatif ini baru memberikan potensi ${ }^{14}$ perlindungan hukum. Mengapa demikian? jawabannya rumusan hukum hanya akan memiliki makna operatif apabila dapat dilaksanakan atau diterapkan pada kasus konkrit, sehingga memiliki makna subjektif pada individu yang menghadapi permasalahan secara konkrit. Itulah sebabnya muncul permasalahan kedua pada perlindungan hukum, yaitu perlindungan hukum pada aras empirik.

Perlindungan hukum pada aras empirik sejatinya adalah kelanjutan dari apa yang dirumuskan dalam norma/kaidah pada aras normatif. Hukum dapat dipahami sebagai rumusan kata-kata yang dibuat oleh pemegang otoritas yang memiliki kewenangan untuk itu. Ketika hukum dirumuskan, selain memiliki tujuan ideal yang ingin diwujudkan sebagai politik hukum, hukum juga memiliki adresat yaitu kelompok tertentu yang menjadi sasaran atau objek pengaturan. Mempertemukan antara rumusan hukum dengan kasus konkrit dalam rangka penegakan hukum, adalah wajah perlindungan hukum pada aras empiris. Dengan demikian perlindungan hukum pada aras empirik memiliki bentuk konkrit penegakan hukum menghadapi permasalahan yang benar-benar terjadi dalam kehidupan masyarakat. Satjipto Rahardjo menyatakan: "hukum sebagai teks itu diam dan hanya melalui perantaraan manusialah ia menjadi "hidup". 15

Perlindungan hukum pada aras normatif dan perlindungan hukum pada aras empiris harus memiliki kesejajaran tanpa menegasikan satu terhadap yang lain. Perlindungan hukum pada aras empiris hanya akan benar apabila berangkat dari perlindungan hukum pada aras normatif sebagai sandarannya. Sebaliknya, sekalipun ada perlindungan hukum pada aras normatif tetapi kalau tidak bisa diwujudkan pada perlindungan hukum pada aras empiris, sejatinya hukum itu mati. Relasi antara hukum sebagai norma dan penegakannya digambarkan secara

13 Soerjono Soekanto, Pengantar Penelitian Hukum Jakarta (UI Press Jakarta 1984) 13.

14 Potensi perlindungan dapat berubah menjadi kekuatan riil perlindungan hukum mana kala potensi tersebut diaktualisasikan melalui tindakan advokasi melalui pejabat negara yang memiliki kewenangan untuk itu. Misalnya hakim yang melalui putusannya bersifat memaksa untuk dipatuhi oleh para pihak. Tetapi potensi perlindungan dapat juga berhenti sebagai potensi yang tidak tidak maujud dalam tindakan nyata. Dalam hal terakhir ini, perlindungan hukum diibaratkan sebagai "macan ompong."

15 Satjipto Raharjo, Hukum dan Perilaku : Hidup Baik adalah Dasar Hukum yang Baik (PT Kompas Media Nusantara Jakarta 2009) 21. 
apik oleh Satjipto dalam relasi antara kerangka (skeleton) ${ }^{16}$ dan pendagingan skeleton (memberikan daging pada kerangka) melalui perilaku (behavior) dalam realitas kehidupan masyarakat. Pada titik ini, konsep perlindungan hukum yang bersifat noumenon maujud dalam tindakan yang secara positif dapat ditengarai dalam tindakan nyata (phenomenon). ${ }^{17}$

Tolak-tarik keterhubungan antara pekerja dan pemberi kerja telah melahirkan kualitas hubungan yang asimetris. Derajat hubungan asimetris ini tidak hanya berpotensi menimbulkan ketidakadilan, tetapi juga penyelesaiannya tidak dapat diserahkan pada mekanisme perjanjian antar para pihak. Penyelesaian secara alamiah hanya akan melanggengkan sifat eksploitatif dari pemberi kerja (yang memiliki posisi determinan dan dominan) dengan buruh (yang memiliki posisi indeterminan dan lemah). Kondisi ini sejatinya telah melahirkan kebutuhan untuk memberikan perlindungan hukum terhadap pekerja. Fithriatus Shalihah dalam penelitiannya yang berjudul Legal Protection of Workers in the Work Agreement on Outsourcing System in Indonesia, menyimpulkan status tenaga outsourcing menjadi masalah karena tidak ada kepastian tentang keberlanjutan hubungan kerja dan tidak terpenuhinya hak-hak yang seharusnya diterima pekerja, sehingga merugikan pekerja secara ekonomi dan sosial. Peraturan yang terkait dengan sistem outsourcing yang dinyatakan dalam UU No. 13 Tahun 2003 tentang Ketenagakerjaan juga sulit diterapkan di dunia bisnis karena aturan yang ada tidak memenuhi kebutuhan pasar tenaga kerja. Dalam pelaksanaan perlindungan pekerjaan dan persyaratan kerja untuk pekerja outsourcing, pemerintah harus meningkatkan perannya dalam pengawasan dan penegakan hukum perburuhan melalui kuantitas dan kualitas pengawas ketenagakerjaan. ${ }^{18}$ Sejalan dengan hasil dari penelitian tersebut, Khairani, dkk. menunjukkan hasil penelitiannya menyatakan bahwa beberapa rumusan hukum yang berkaitan dengan perlindungan pekerja mengandung kontradiksi antar konsep (contradictio adconceptio). ${ }^{19}$ Dari perspektif yang lain, Niru Anita Sinaga, dkk menyatakan 20 :

"Indonesia has not run properly due to various supervision and law enforcement. However, the use of outsourcing is needed and does not need to be removed. So that all parties can accept its existence necessary revisions to existing regula- tions, tightened supervision, and law enforce- ment is really done in order to provide legal protection for the parties. Legal protection of the parties must be guaranteed its implementation..........."

Dari berbagai hasil penelitian tersebut menunjukkan bahwa dalam hubungan kerja, pekerja sejatinya tidak dalam posisi yang equal tetapi tersubordinasikan oleh pengusaha yang juga berposisi sebagai pemberi kerja. Persoalan posisi pekerja ini

Hukum yang dipahami sebatas teks-teks yang tertulis (lex scripta) saja dapat diibaratkan sebagai pemahaman "mayat-mayat hukum" yang tidak terelasi dengan kehidupan nyata. Ini bukan "hukum sebenarnya". Bandingkan, Satjipto Raharjo, Ibid., 14.

17 Pemisahan sekaligus relasi antara nomena dan fenomena dapat dibaca dalam: Laily Muthmainnah, ‘Tinjauan Kritis terhadap Epistimologi Immanuel Kant (1724-1804)' (2018) 28 (1) Jurnal Filsafat 74, 86-88.

18 Fithriatus Shalihah, 'Legal Protection of Workers in the Work Agreement on Outsourcing System in Indonesia' (2017) 6 (3) Yustitia 589.

19 Khairani, 'Realizing Legal Protection for Outsourcing Worker Through Employment Setting Synchronization' (2015) 15 (3) Jurnal Dinamika Hukum 260, 264.

20 Niru Anita Sinaga, Basuki Rekso Wibowo, Sri Gambir Melati Hatta, Fauzie Yusuf Hasibuan, 'Aligment of Outsoucing Agreement on Protection Law and Justice' (2015) 1(1) The Southeast Asia Law Journal 23, 30. 
akan menjadi semakin termarjinalkan terutama terhadap pekerja yang terikat dengan PKWT dan tenaga kerja alih daya (outsourcing).

\section{Multi Tafsir Konstantasi Hukum "Demi Hukum"}

Perlindungan hukum terhadap pekerja yang terikat dengan PKWT dan tenaga alih daya (outsourcing) secara normative telah terumuskan dengan konstantasi legal "demi hukum" terhadap peralihan status hubungan kerja dari PKWT menjadi PKWTT dan dari tenaga kerja alih daya menjadi pekerja perusahaan pemberi kerja. Secara teoritik, konstatasi legal "demi hukum" sebenar merupakan bentuk perlindungan hukum yang paling tinggi. Sebab, manakala persyaratan terpenuhi seharusnya konsekuensi hukum secara otomatis (seharusnya) diterapkan. Atau, atas wibawa hukum konsekuensi hukum itu harus dapat direalisasikan pada praxis hukum. Ketentuan ini sejatinya bersifat preskriptif. (Seharusnya) Tidak ada kesenjangan antara perlindungan hukum pada aras normatif dan perlindungan hukum pada aras empiris. Namun kenyataannya tidak demikian. Permasalahan ini, akan dikaji dengan membedah 3 (tiga) putusan MK, yaitu Putusan MK No. 7 /PUUXII/2014, Putusan MK No. 96/PUU-VII/2013, dan Putusan MK No. 27/PUUIX/2011.

Tiga putusan MK tersebut bukan hanya memiliki kemiripan tinggi tetapi juga memiliki perbedaan yang signifikan. Alih-alih menolak, amar pada putusan tersebut secara diametral bertolak belakang dan bukan diputuskan tidak diterima atas dasar asas ne bis in idem. Persamaannya adalah sama-sama menyoal konstitusionalitas terhadap Pasal 59 ayat (7), Pasal 65 ayat (8), dan Pasal 66 ayat (4) UU No. 13 Tahun 2003 tentang Ketenagakerjaan. Perbedaannya, Putusan MK No. 27/PUU- IX/2011, para Pemohon memusatkan permohonannya pada pihak ketiga yaitu penyedia tenaga kerja. Putusan MK No. 96/PUU-XI/2013 dan Putusan MK No. 27/PUUIX/2011 Pemohon menitikberatkan pada permohonan penafsiran frasa "demi hukum", tetapi Majelis Hakim Konstitusi berpandangan :

"........meskipun dasar pengujian permohonan a quo sama dengan Putusan MK No. 96/PUU-XI/2013 dan sama-sama memohon penafsiran frasa "demi hukum" namun sesungguhnya alasan konstitusionalnya tidaklah sama. Pemohon dalam Putusan MK No. 96/PUU-XI/2013 mendasarkan pada tidak adanya penafsiran hukum yang pasti oleh pembentuk undang-undang terhadap norma a quo dan tidak adanya aturan mengenai lembaga yang berwenang menyatakan terpenuhi atau tidak terpenuhinya syarat-syarat dalam perjanjian waktu tertentu sehingga menurut Pemohon a quo frasa "demi hukum" dalam Pasal 59 ayat (7), Pasal 65 ayat (8), dan Pasal 66 ayat (4) UU No.13 Tahun 2003 bertentangan dengan UUD 1945 sepanjang tidak dimaknai "setelah adanya putusan berkekuatan hukum tetap dari badan yang melaksanakan fungsi yang berkaitan dengan kekuasaan kehakiman, dalam hal ini Pengadilan Hubungan Industrial pada Pengadilan Negeri........ Sedangkan perkara No. 7/PUU-XII/2014 lebih mendasarkan pada upaya hukum yang dapat dilakukan setelah terbitnya nota pemeriksaan pegawai pengawas ketenagakerjaan yang tidak dilaksanakan oleh pemberi kerja dan/atau perusahaan pemberi kerja, sehingga menurut Pemohon frasa "demi hukum" dalam Pasal 59 ayat (7), Pasal 65 ayat (8), dan Pasal 66 ayat (4) UU 13 No. 13 Tahun 2003 bertentangan dengan UUD 1945..........."

Putusan MK terhadap ketiga permohonan tersebut juga berbeda. Putusan MK No. 27/PUU-IX/2011, mengabulkan permohonan pemohon untuk sebagian. Putusan MK No. 96/PUU-VII/2013, permohonan pemohon ditolak seluruhnya. 
Sedang dalam Putusan MK No. 7/PUU-XII/2014, mengabulkan permohonan pemohon.

Terhadap konstatasi "demi hukum" sebagaimana terumus dalam Pasal 59 ayat (7), Pasal 65 ayat (8), dan Pasal 66 ayat (4) UU No. 13 Tahun 2003 dipersepsikan secara berbeda diantara dua pihak yang secara diametral berhadap-hadapan. Tidak pelak lagi, kepentingan subjektiflah yang melatarbelakanginya. Dalam permohonan yang terregister dalam Buku Registrasi Perkara Konstitusi pada tanggal 11 November 2013 dengan No. 96/PUU-XI/2013, Sofyan Wanandi dalam jabatannya sebagai Ketua Umum APINDO dan Suryadi Sasmita dalam jabatannya sebagai Sekretaris Jenderal APINDO mengajukan pengujian dalam permohonan ini diharapkan agar norma ketenagakerjaan yang dimohonkan diuji dalam permohonan a quo dapat memberikan jaminan perlindungan hukum, kepastian hukum serta penegakan hukum yang adil sesuai dengan amanat konstitusi. Menurut APINDO sebagai pemohon judicial review, berpandangan bahwa istilah "demi hukum" menimbulkan multi tafsir. Setidaknya terdapat 3 (tiga) implikasi dari yang ditafsirkan oleh stake holders, yaitu:

a. Demi hukum status hubungan kerja pekerja/buruh dengan perusahaan penerima pemborongan beralih menjadi hubungan kerja pekerja/buruh dengan perusahaan pemberi pekerjaan, namun mengenai tidak terpenuhi norma kerja pada norma a quo perlu dibuktikan terlebih dahulu melalui gugatan perdata melalui badan peradilan yaitu Pengadilan Hubungan Industrial. Pembuktian melalui badan peradilan diperlukan setidaknya untuk memberikan kepastian hukum bahwa suatu norma terpenuhi atau tidak terpenuhi, sekaligus memberikan kepastian hukum tentang konsekuensikonsekuensinya yaitu hal- hal menyangkut peralihan status hubungan kerja dan khususnya berkaitan dengan perhitungan hak-hak pekerja/buruh;

b. Demi hukum status hubungan kerja pekerja/buruh dengan perusahaan penerima pemborongan beralih menjadi hubungan kerja pekerja/buruh dengan perusahaan pemberi pekerjaan, namun mengenai tidak terpenuhi norma kerja pada norma a quo dibuktikan dengan adanya nota pengawasan dari instansi yang bertanggungjawab di bidang ketenagakerjaan dan selanjutnya apabila pihak perusahaan pemberi pekerjaan tidak melaksanakan nota pengawasan tersebut maka salah satu pihak dapat menyelesaikannya melalui Pengadilan Hubungan Industrial untuk memperoleh suatu hak;

c. Demi hukum status hubungan kerja pekerja/buruh dengan perusahaan penerima pemborongan beralih menjadi hubungan kerja pekerja/buruh dengan perusahaan pemberi pekerjaan, namun mengenai pelanggaran norma kerja pada norma a quo dibuktikan dengan adanya nota pengawasan dari instansi yang bertanggungjawab di bidang ketenagakerjaan dan selanjutnya tanpa proses melalui badan peradilan pekerja/buruh serta merta mempunyai hubungan kerja dengan perusahaan pemberi pekerjaan.

Menurut APINDO, guna memberikan suatu kepastian hukum terhadap terpenuhi atau tidaknya suatu norma diperlukan pemeriksaan melalui pengadilan dan menggunakan hukum pembuktian, sehingga terhadap frasa: "demi hukum" dalam Pasal 59 ayat (7), 65 ayat (8) dan Pasal 66 ayat (4) UU 13 Tahun 2003 tentang Ketenagakerjaan perlu diberikan suatu persyaratan atau makna tersendiri yaitu demi hukum dimaknai setelah adanya putusan berkekuatan hukum tetap dari 
badan yang melaksanakan fungsi berkaitan dengan kekuasaan kehakiman, dalam hal ini Pengadilan Hubungan Industrial pada Pengadilan Negeri. Pandangan APINDO yang menentukan bahwa terpenuhi syarat sehingga klausula "demi hukum" dapat diterapkan seharusnyalah ditentukan oleh pengadilan dan menggunakan hukum pembuktian, sehingga prasa demi hukum perlu diberikan persyaratan atau makna tersendiri yaitu demi hukum dimaknai setelah adanya putusan berkekuatan hukum tetap dari badan yang melaksanakan fungsi berkaitan dengan kekuasaan kehakiman, dalam hal ini Pengadilan Hubungan Industrial pada Pengadilan Negeri.

Terhadap permohonan tersebut, MK menolak permohonan pemohon untuk seluruhnya. Argumen dari MK pada pokoknya adalah sebagai berikut:

a. jika frasa "demi hukum" dalam pasal a quo dimaknai perubahan status pekerja berubah setelah adanya putusan yang berkekuatan hukum tetap oleh pengadilan akan berakibat perubahan makna batal demi hukum menjadi dapat dibatalkan. Implikasinya, selama tidak ada putusan pengadilan maka perjanjian kerja yang bertentangan dengan Undang-Undang tersebut dilegitimasi dan dianggap sah. Dengan diperlukannya putusan pengadilan lebih dahulu akan berpotensi terlanggarnya keadilan bagi kaum pekerja dan buruh.

b. dalam konteks perkara a quo, frasa "demi hukum" sebagaimana termaktub dalam Pasal 59 ayat (7), Pasal 65 ayat (8), dan Pasal 66 ayat (4) UU No. 13 Tahun 2003 berkaitan dengan syarat yang harus dipenuhi dalam perubahan status dari PKWT menjadi PKWTT. Ketentuan mengenai syarat-syarat tersebut justru merupakan jaminan kepastian hukum yang adil bagi para pihak dalam hubungan kerja dimaksud;

c. adanya multitafsir terhadap frasa "demi hukum" dalam pelaksanaannya di lapangan, baik dari perspektif pengusaha maupun pekerja/buruh dalam perkara a quo merupakan problem hukum yang bersifat implementatif dari pelaksanaan Undang-Undang, bukan merupakan problem hukum yang bersifat pertentangan norma Undang-Undang terhadap UUD 1945.

Penolakan MK terhadap permohonan pemohon (Apindo) yang secara posisional adalah representasi dari pengusaha dalam perkara No. 96/PUU-XI/2013, dapat ditafsirkan sebagai keberpihakan MK terhadap pekerja. Dalam pandangan MK, kalau permohonan Apindo dikabulkan akan terjadi proses perumitan birokrasi yang akan bermuara pada ketidak-pastian hukum bagi pekerja. Pandangan MK ini dapat ditafsirkan bahwa basis perlindungan terhadap pekerja atas dasar doktrin batal demi hukum (null and void) tidak boleh digradasi menjadi perlindungan atas dasar dapat dibatalkan (voidable). Implementasi dari perlindungan hukum atas dasar (batal) demi hukum pada hubungan kerja antara pekerja PKWT dan pekerja alih daya secara otomatis akan terjadi tanpa harus didasarkan pada putusan pengadilan (baca: Pengadilan Hubungan Industrial/PHI) yang telah berkekuatan hukum tetap. Dengan meminjam istilah Clifford Geerz, ${ }^{21}$ MK menolak involusi hukum dalam

$21 \quad$ Clifford Geerz, dkk., Involusi Pertanian, Proses Perubahan Ekologi di Indonesia (cet. ke 2, Bhatara Karya Aksara 1983) menggunakan diksi involusi sebagai negasi dari evolusi. Involusi dimaknai sebagai kemunduran. Diksi involusi kemudian dipinjam dan dipergunakan untuk bidang kajian politik, misalnya Zuly Qodir, Involusi Politik Pemekaran, Etnisitas, dan Agama : Tantangan Reformasi Birokrasi Kasus Maluku Utara' (2012) 4 (4) Jurnal Bina Praja. (retrieved from http://jurnal.kemendagri.go.id/index.php/jbp/article/view/74/71) diunduh 18 Agustus 2020. 
pemberian perlindungan hukum terhadap pekerja.

Pekerja, mempersepsikan konstatasi “demi hukum" sebagaimana terumus dalam Pasal 59 ayat (7), Pasal 65 ayat (8), dan Pasal 66 ayat (4) UU No. 13 tahun 2003 dalam aras praxis belum mampu memberikan perlindungan kepada pemohon. Dari perspektif pekerja, frasa "demi hukum" tidak juga dapat menjadi dasar untuk merubah status dari PKWT menjadi PKWTT atau dari pegawai alih daya (outsourcing) menjadi pegawai perusahaan pemberi pekerjaan. Alasan pekerja mengajukan judicial review selain yang telah dipaparkan tersebut adalah :

a. Pembentuk Undang-Undang hanya mengatur sepanjang tata cara penyelesaian penyimpangan norma yang mengandung unsur tindak pidana ketenagakerjaan dalam UU No. 13 tahun 2003 tentang Ketenagakerjaan. Tetapi, tidak mengatur mengenai tata cara bagaimana pelaksanaan (eksekusi) atas penetapan tertulis dari instansi yang bertanggung jawab dibidang ketenagakerjaan pada pemerintah pusat, pemerintah provinsi, dan pemerintah kabupaten/kota, yang tidak dimintakan pemeriksaan ke Pengadilan Tata Usaha Negara, dan juga tidak dijalankan secara sukarela oleh pengusaha/majikan. Sehingga, terdapat kekosongan hukum yang dapat menimbulkan kerugian para Pemohon.

b. penetapan tertulis dari instansi yang bertanggung jawab dibidang ketenagakerjaan pada pemerintah pusat, pemerintah provinsi, dan pemerintah kabupaten/kota, yang bersifat konkret, individual, dan final, yang menimbulkan akibat hukum bagi seseorang atau badan hukum perdata, tidak dipatuhi/dijalankan oleh pengusaha/majikan, maka untuk memberikan pengakuan, jaminan, perlindungan, dan kepastian hukum status hubungan kerja pekerja/buruh, serta untuk tetap menjaga hubungan industrial yang kondusif, dan agar menjadi tidak sia-sia atas terbitnya penetapan tertulis dari instansi yang bertanggung jawab dibidang ketenagakerjaan pada pemerintah pusat, pemerintah provinsi, dan pemerintah kabupaten/kota, yang bersifat final dan bermakna berkekuatan hukum, seharusnya pelaksanaan penetapan tertulis dari instansi yang bertanggung jawab dibidang ketenagakerjaan pada pemerintah pusat, pemerintah provinsi, dan pemerintah kabupaten/kota, dapat dimintakan pelaksanaannya ke Pengadilan Negeri melalui Pengadilan Hubungan Industrial.

Terhadap permohonan pekerja yang terregister dalam buku register Buku Registrasi Perkara Konstitusi dengan No. 7/PUU-XII/2014 pada tanggal 22 Januari 2014, MK memutuskan mengabulkan permohonan para pemohon, dengan argumentasi sebagai berikut :

a. Mahkamah berpendapat bahwa pengawasan terhadap pelaksanaan peraturan perundang-undangan, khususnya peraturan perundang-undangan yang terkait dengan ketenagakerjaan merupakan salah satu upaya menciptakan hubungan industrial yang harmonis dan berkeadilan serta menjamin penegakan hukum dan perlindungan bagi tenaga kerja. Tujuan pengawasan Ketenagakerjaan sebagaimana diatur dalam UU No. 3 Tahun 1951 tentang Pernyataan Berlakunya Undang-Undang Pengawasan Perburuhan Tahun 1948 NR. 23 Dari Republik Indonesia Untuk Seluruh Indonesia (Lembaran Negara Tahun 1951), sejalan pula dengan UU No. 13 Tahun 2003 tentang Ketenagakerjaan dan Konvensi ILO No. 81 mengenai Pengawasan 
Ketenagakerjaan Dalam Industri dan Perdagangan yang telah diratifikasi oleh Pemerintah Republik Indonesia.

b. Berdasarkan UU No. 13 Tahun 2003 tentang Ketenagakerjaan jo. PP No. 21 Tahun 2010 tentang Pengawas Ketenagakerjaan memberikan kewenangan kepada Pemerintah, dalam hal ini pegawai pengawas ketenagakerjaan, untuk mengawasi pelaksanaan hukum ketenagakerjaan.

c. Menurut Mahkamah, penetapan tertulis pegawai pengawas ketenagakerjaan merupakan Keputusan Tata Usaha Negara yang bersifat konkret, individual, dan final yang menimbulkan akibat hukum bagi seseorang atau badan hukum perdata sebagaimana diatur dalam Pasal 1 angka 9 UU No. 51 Tahun 2009. Oleh karenanya, penetapan tertulis yang dikeluarkan oleh pegawai pengawas ketenagakerjaan tersebut haruslah dianggap benar sebelum dibuktikan sebaliknya dan dibatalkan;

d. Menurut Mahkamah, pegawai pengawas ketenagakerjaan berwenang untuk mengawasi pelaksanaan Pasal 59, Pasal 65, dan Pasal 66 UU No. 13 Tahun 2003 termasuk menentukan terpenuhi atau tidak terpenuhinya persyaratan sebagaimana diatur dalam Pasal 59 ayat (1), ayat (2), ayat (4), ayat (5), dan ayat (6); Pasal 65 ayat (2) dan ayat (3); serta Pasal 66 ayat (1), ayat (2) huruf a, huruf b, huruf d, dan ayat (3) UU No. 13 Tahun 2003 dan karenanya berwenang pula mengeluarkan nota pemeriksaan dan/atau penetapan tertulis terkait hal tersebut.

e. Menurut Mahkamah, untuk menegakkan pelaksanaan ketentuan ketenagakerjaan serta memberikan perlindungan dan kepastian hukum bagi bagi pekerja/buruh, pengusaha dan pemberi pekerjaan sebagaimana dijamin dalam Pasal 28D ayat (1) UUD 1945, pekerja/buruh dapat meminta pelaksanaan nota pemeriksaan pegawai pengawas ketenagakerjaan dimaksud kepada Pengadilan Negeri setempat. Dengan mendasarkan pada pertimbangan tersebut maka frasa "demi hukum" dalam Pasal 59 ayat (7), Pasal 65 ayat (8), dan Pasal 66 ayat (4) UU No. 13 Tahun 2003 inkonstitusional bersyarat sepanjang tidak dimaknai, "Pekerja/buruh dapat meminta pengesahan nota pemeriksaan pegawai pengawas ketenagakerjaan kepada Pengadilan Negeri setempat dengan syarat:

1) Telah dilaksanakan perundingan bipartit namun perundingan bipartit tersebut tidak mencapai kesepakatan atau salah satu pihak menolak untuk berunding; dan

2) Telah dilakukan pemeriksaan oleh pegawai pengawas ketenagakerjaan berdasarkan peraturan perundang-undangan";

Putusan MK pada permohonan a quo yang mengabulkan permohonan pemohon (baca pekerja), sejatinya memiliki kesejajaran pandangan dengan Putusan MK No. 96/PUU-XI/2013. Bahkan, apabila keduanya disintesakan melahirkan konsep perlindungan hukum bagi pekerja yang saling melengkapi. 


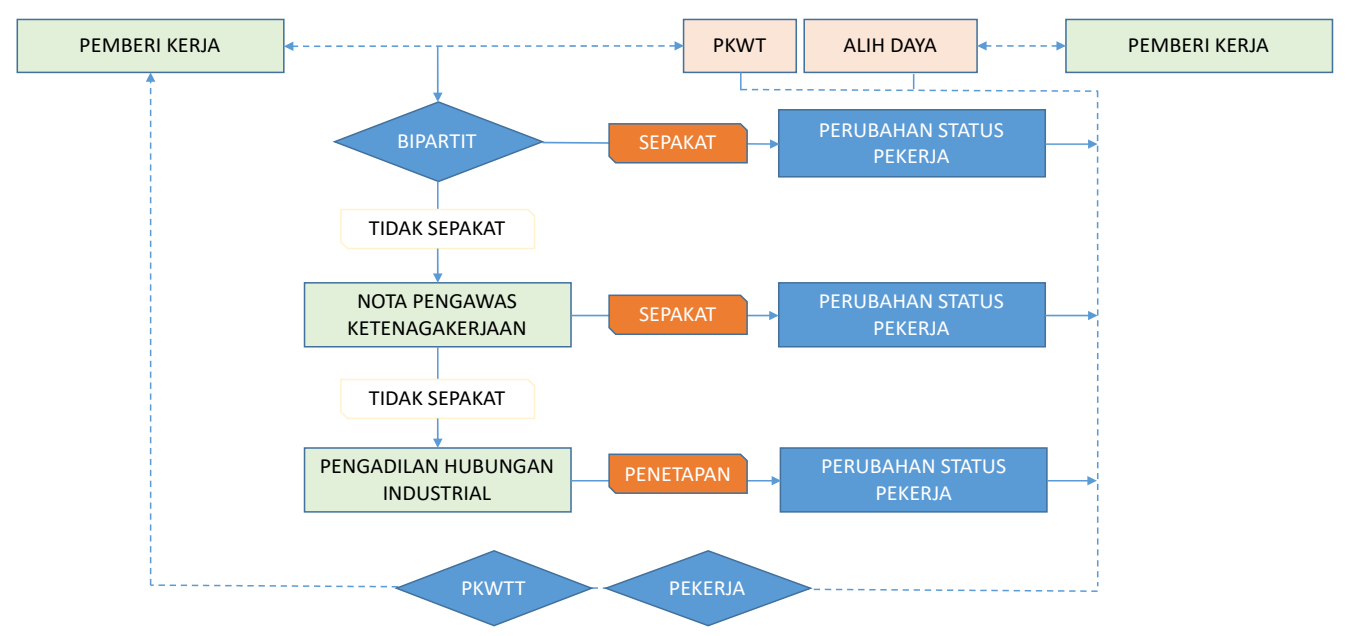

\section{Norma Perlindungan Buruh Secara Berjenjang Oleh Mahkamah Konstitusi}

Perbedaan pandangan MK pada Putusan MK No. 96/PUU-XI/2013 dan Putusan MK No. 7/PUU-XII/2014 terletak pada implementasi perubahan status pekerja PKWT menjadi PKWTT dan pekerja alih daya dari hubungan hukum antara pekerja dengan perusahaan alih daya (outsourcing) menjadi hubungan hukum antara pekerja alih daya dengan perusahaan pemberi pekerjaan. Pada Putusan MK No. 96/PUU-XI/2013 berpendapat bahwa multi tafsir terkait dengan implementasi frasa 'demi hukum' baik dari perspektif pengusaha maupun buruh/pekerja dinilai :

"merupakan problem hukum yang bersifat implementatif dari pelaksanaan UndangUndang, bukan merupakan problem hukum yang bersifat pertentangan norma Undang-Undang terhadap UUD 1945. Jikalaupun terdapat ketidaktaatan salah satu pihak dalam pelaksanaannya sebagaimana disyaratkan dalam Undang-Undang maka hal itu menjadi kewenangan pemerintah, khususnya yang menyelenggarakan urusan di bidang ketenagakerjaan, yang salah satu fungsinya adalah untuk melakukan pengawasan agar para pihak mentaati peraturan perundang-undangan yang berlaku, khususnya UU No. 13 Tahun 2003.”

Sementara MK dalam Putusan MK No. 7/PUU-XII/2014 memberi jalan keluar terhadap multi tafsir implementasi frasa 'demi hukum' dengan menetapkan langkah secara berjenjang sebagaimana tergambar dalam bagan pada bagian terdahulu. Intinya, implementasi dilakukan : (a) secara bipartit, (b) dilakukan pemeriksaan oleh pegawai pengawas ketenagakerjaan dengan menerbitkan nota pemeriksaan, (c) meminta pengesahan nota pemeriksaan pegawai pengawas ketenagakerjaan kepada Pengadilan Negeri setempat.

Satu aspek yang perlu dicermati dari Putusan MK No. 7/PUU-XII/2014 adalah pengadilan mana yang memiliki kewenangan untuk mengesahkan nota pemeriksaan pegawai pengawas ketenagakerjaan? Pengadilan Negeri setempat atau Pengadilan Hubungan Industrial/PHI (setempat)? Menurut hemat penulis, implementasi frasa 'demi hukum' dalam kasus ini merupakan bentuk perselisihan industrial. Dengan demikian secara substantif, persoalan ini seharusnya menjadi kompetensi PHI. Namun demikian, penulis menyadari bahwa pandangan penulis terakhir ini mengandung kelemahan, terlalu birokratis. Mengingat, PHI tidak selalu ada pada daerah kabupaten/kota. Entah disadari atau tidak oleh MK, pilihan 'Pengadilan Negeri setempat' ini merupakan bentuk debirokratisasi perlindungan hukum bagi buruh/pekerja tetapi memunculkan benturan kompetensi pengadilan. 
Terkait dengan tolak-tarik perlindungan hukum pada aras normatif dan pada aras empiris ini antara lain dapat ditemukan dalam Putusan MK No. 7/PUUXII/2014. Pasal 59 ayat (7), Pasal 65 ayat (8), dan Pasal 66 ayat (4) UU No. 13 Tahun 2003 tentang Ketenagakerjaan yang merumuskan kemungkinan peralihan status pekerja atas dasar Perjanjian Kerja Waktu Tertentu (PKWT) menjadi pekerja atas dasar Perjanjian Kerja Waktu Tidak Tertentu (PKWTT) atau dari hubungan kerja antara pekerja/buruh dengan perusahaan penerima pemborongan beralih menjadi hubungan kerja antara pekerja/buruh dengan perusahaan-perusahaan pemberi pekerjaan, atau, hubungan kerja antara pekerja/buruh dan perusahaan penyedia jasa pekerja/buruh beralih menjadi hubungan kerja antara pekerja/buruh dan perusahaan pemberi pekerjaan. Ketiga bentuk peralihan status hubungan kerja ini terjadi "demi hukum". Secara skematik, tolak-tarik tersebut dapat digambarkan sebagai berikut:

Terhadap tolak-tarik kepentingan antara pemberi kerja dan pekerja terebut, menurut penulis MK telah meletakkan dasar perlindungan hukum yang lebih jelas terhadap pekerja. Dengan menolak permohonan APINDO salah satunya berdasarkan argumen jika permohonan APINDO dikabulkan, akan mengakibatkan perubahan makna (batal) demi hukum menjadi dapat dibatalkan. Jika hal demikian terjadi, sejatinya akan menggradasi perlindungan hukum pekerja menjadi lebih rendah. MK melalui putusannya, Putusan MK No. 7/PUU-XII/2014 justru memperkuat perlindungan hukum terhadap pekerja dengan menetapkan kedudukan Nota Dinas/Penetapan tertulis Pegawai Pengawas Ketenagakerjaan sebagai tindakan Tata Usaha Negara (TUN) yang menimbulkan akibat TUN bagi pekerja/buruh dan perusahaan tertentu. Oleh karenanya, penetapan tertulis yang dikeluarkan oleh pegawai pengawas ketenagakerjaan tersebut haruslah dianggap benar sebelum dibuktikan sebaliknya dan dibatalkan. Terhadap kemungkinan penolakan pemberi kerja atas Nota Dinas Pegawai Ketenagakerjaan sebagai dasar perubahan status pekerja (PKWT dan alih daya) yang sifatnya "demi hukum", MK memberikan jalan keluar bagi pekerja yang dirugikan untuk (dapat) meminta penetapan pengadilan setempat. Dengan demikian, sikap MK dengan menolak permohonan APINDO dan mengabulkan permohonan pekerja, sejatinya telah meletakkan dasar perlindungan hukum bagi pekerja terkait dengan perubahan status yang sifatnya demi hukum dari PKWT menjadi PKWTT dan dari pekerja alih daya menjadi pekerja dari perusahaan pemberi kerja.

\section{Putusan MK Masih Menyisakan Ketidakpastian Perlindungan Hukum Pada Aras Empirik}

Permasalahannya adalah, apakah dengan putusan MK ini pekerja sebagai pihak yang memiliki posisi tawar terhadap pemberi kerja sudah terlindungi? menurut penulis, terhadap problematika peralihan status yang sifatnya demi hukum pekerja telah cukup terlindungi. Tetapi perlindungan ini sejatinya masih terbatas perlindungan hukum pada aras normatif saja. Perlindungan hukum pada aras empirik masih meninggalkan problema hipotetik tersendiri. Beberapa problematika hipotetik ini dapat ditengarai antara lain:

1. Nota Dinas Pegawai Pengawas Ketenagakerjaan yang menjadi dasar perubahan status demi hukum bagi pekerja terbuka dipersoalkan oleh pemberi kerja 
melalui Peradilan Tata Usaha Negara. MK telah mengambil putusan bahwa Pegawai Pengawas Ketenagakerjaan adalah badan atau pejabat yang melaksanakan urusan pemerintahan berdasarkan peraturan perundangundangan.22 Dengan pengakuan Pegawai Pengawas Ketenagakerjaan adalah pejabat TUN, maka keputusan Pegawai Pengawas Ketenagakerjaan (termasuk di dalamnya adalah penilaian Pegawai Pengawas Ketenagakerjaan untuk menilai persyaratan PKWT atau alih daya) merupakan keputusan yang dapat digugat di Peradilan Tata Usaha Negara (PTUN).

2. Sekalipun MK telah memberi jalan apabila nota dinas Pegawai Pengawas Ketenagakerjaan tidak dipatuhi oleh perusahaan pemberi kerja atau perusahaan pemberi pekerjaan, dapat meminta pelaksanaan nota pemeriksaan Pegawai Pengawas Ketenagakerjaan dimaksud kepada Pengadilan Negeri setempat sebagai the last resort perlindungan hukum bagi pekerja, tetapi masalah dapat (juga) muncul apabila Pengadilan Negeri menolak permohonan pelaksanaan nota dinas tersebut. Penolakan permohonan pelaksanaan nota dinas seharusnya tidak terjadi apabila Pengadilan Negeri diposisikan sebagai pelaksana (eksekutor) nota dinas. Hal ini sejalan dengan pertimbangan MK yang menyatakan : "Bahwa frasa "demi hukum" yang terdapat dalam Pasal 59 ayat (7), Pasal 65 ayat (8) dan Pasal 66 ayat (4) UU No. 13 Tahun 2003 tentang Ketenagakerjaan bersifat langsung dapat dilaksanakan (mempunyai title eksekutorial) atau berlaku dengan sendirinya." Tetapi tetap harus diakui bahwa kesamaan sikap Pengadilan Negeri belum tentu sama. Permasalahan lanjutannya adalah apa yang bisa dilakukan oleh pekerja apabila Pengadilan Negeri menolak pelaksanaan nota dinas Pegawai Pengawas Ketenagakerjaan? pada titik inilah sebenarnya perlindungan hukum terhadap pekerja pada aras empiric masih menimbulkan tanda tanya.

3. Perlindungan hukum terhadap pekerja pada aras normative telah memperoleh titik terang dengan ditolaknya permohonan APINDO melalui Putusan MK No. 96/PUU-VII/2013 dan dikabulkannya permohonan pekerja melalui Putusan MK No. 7/PUU-XII/2014, tetapi ketika implementasinya diserahkan sepenuhnya pada dinamika peradilan, sangat berpotensi mendistorsi posisi buruh. Dengan mengadopsi teori sibernetik dari Robert Seidman, ketika terjadi tolak-tarik antara nilai dan kekuatan ekonomi, sangat mungkin putusan Pengadilan Negeri akan terjerembab pada kekuatan ekonomi. Pada titik krusial ini, pekerja akan menghadapi tembok besar kekuatan ekonomi pengusaha yang notabene menjadi pemberi kerja atau pemberi pekerjaan.

\section{PENUTUP}

Perjuangan buruh/karyawan dalam rangka memperoleh perlindungan hukum yang lebih berkepastian, dilakukan antara lain dengan mengajukan judicial review terhadap UU No. 13 Tahun 2003 tentang Ketenagakerjaan. Jaminan hukum peralihan status PKWT menjadi PKWTT dan beralihnya hubungan hukum tenaga 
kerja alih daya dengan perusahaan penyedia tenaga kerja menjadi hubungan hukum dengan perusahaan pemberi pekerjaan yang bersifat "demi hukum" apabila terjadi pelanggaran hukum sebagaimana diatur dalam Pasal 65 ayat (8) dan Pasal 66 ayat (4) UU No. 13 Tahun 2003 menimbulkan multitafsir diantara pengusaha sebagai pemberi kerja dan buruh/karyawan yang berpotensi menimbulkan ketidakpastian hukum. Putusan MK No. 96/PUU-XI/2013 dan Putusan MK No. 7/PUU-XII/2014 apabila disintesakan memberikan perlindungan hukum yang lebih konkrit dalam implementasi frasa "demi hukum," yaitu dengan memberikan langkah secara berjenjang sebagai berikut :

a. Implementasi peralihan status buruh yang bersifat demi hukum diserahkan pada mekanisme perundingan bipartit.

b. Apabila perundingan secara bipartit gagal, buruh dapat minta nota pemeriksaan Pegawai Pengawas Ketenagakerjaan. Dengan nota tersebut buruh dapat meminta pemberi kerja melaksanakan peralihan status buruh.

c. Apabila langkah pada point (b) tersebut gagal, buruh dapat meminta pengesahan nota pemeriksaan Pegawai Pengawas Ketenagakerjaan ke Pengadilan Negeri setempat.

Sekalipun putusan MK telah memberi makna frasa "demi hukum," menjadi lebih konkrit dan operasional, hal ini belum sepenuhnya memberi perlindungan hukum pada aras empirik, karena perlindungan hukum masih terhenti pada aras normatif. Perlindungan hukum pada aras empirik sejatinya bentuk keberlanjutan hukum aras normatif, yang implementasinya sangat tergantung pada ketaatan hukum pengusaha sebagai pemberi kerja.

\section{DAFTAR REFERENSI}

\section{Buku}

Asshiddiqie J, Konstitusi Ekonomi (PT Kompas Media Nusantara Jakarta 2010).

Geerz C., dkk., Involusi Pertanian, Proses Perubahan Ekologi di Indonesia (cet. ke 2, Bhatara Karya Aksara 1983).

Hadjon PM, Perlindungan Hukum Bagi Rakyat Indonesia, Studi mengenai PrinsipPrinsip Penangannya oleh Pengadilan dalam Lingkup Peradilan Umum dan Pembentukan Peradilan Administratif Negara (Bina Ilmu Surabaya 1987.

Raharjo S, Hukum dan Perilaku: Hidup Baik adalah Dasar Hukum yang Baik (PT Kompas Media Nusantara Jakarta 2009).

Soekanto S, Pengantar Penelitian Hukum Jakarta (UI Press Jakarta 1984).

Sudjatmoko, Dialog Indonesia dan Masa Depan (Usaha Offset Surabaya 1992).

Suseno FM, Pemikiran Karl Marx: Dari Sosialisme Utopis ke Perselisihan Revisionisme (Gramedia Pustaka Utama Jakarta 2010).

\section{Artikel Jurnal}

Zuhdan M, 'Perjuangan Gerakan Buruh Tidak Sekedar Upah, Melacak Perkembangan Isu Gerakan Buruh di Indonesia Pasca Reformasi' (2014) 17 (3) Jurnal Ilmu Sosial dan Ilmu Politik. 
Muthmainnah L, 'Tinjauan Kritis terhadap Epistimologi Immanuel Kant (17241804)' (2018) 28 (1) Jurnal Filsafat.

Fithriatus Shalihah, 'Legal Protection of Workers in the Work Agreement on Outsourcing System in Indonesia' (2017) 6 (3) Yustitia.

Khairani, 'Realizing Legal Protection for Outsourcing Worker Through Employment Setting Synchronization' (2015) 15 (3) Jurnal Dunia Hukum.

Niru Anita Sinaga, Basuki Rekso Wibowo, Sri Gambir Melati Hatta, Fauzie Yusuf Hasibuan, 'Aligment of Outsoucing Agreement on Protection Law and Justice' (2015) 1 (1) The Southeast Asia Law Journal.

Alam TG, et. all., 'Revolusi Industri Keempat : Akhir dari Buruh di Seluruh Dunia' (2019) 12 (2) Jurnal Hubungan Internasional.

Qodir Z, 'Involusi Politik Pemekaran, Etnisitas, dan Agama: Tantangan Reformasi Birokrasi Kasus Maluku Utara' (2012) 4 (4) Jurnal Bina Praja.

Ismail I dan Basir MZK, 'Karl Marx dan Perjuangan Kelas' (2012) 1 (June) International Journal of Islamic Thought.

\section{Website}

Budi DP. 'Sejarah Revolusi Industri1.0 hingga 4.0' (otomasi 9 Oktober 2018) $<$ https://otomasi.sv.ugm.ac.id/2018/10/09/sejarah-revolusi-industri-1-0hingga-4-0/> diakses 27 April 2020

Mulyanawati T, 'Masalah Ketenagakerjaan Selama 2019, Kasus PKWT Mendominasi' (Kabar Banten, 8 Januari 2020) < https://kabarbanten.pikiranrakyat.com/serang/pr-59623797/masalah-ketenagakerjaan-selama-2019kasus-pkwt-mendominasi?page $=2>$ diakses 30 April 2020 .

\section{Putusan Pengadilan}

Putusan Mahkamah Konstitusi Nomor 12/PUU-I/2003, Mahkamah Konstitusi, 28 Oktober 2004.

Putusan Mahkamah Konstitusi Nomor 27/PUU-IX/2011, Mahkamah Konstitusi, 17 Januari 2012.

Putusan Mahkamah Konstitusi Nomor 96/PUU-VII/2013, Mahkamah Konstitusi, 7 Mei 2014.

Putusan Mahkamah Konstitusi Nomor 7/PUU-XII/2014, Mahkamah Konstitusi, 4 November 2015.

\section{Peraturan Perundang-Undangan}

Undang-Undang Dasar Negara Republik Indonesia 1945

Undang-Undang Nomor 13 Tahun 2003 tentang Ketenagakerjaan.

Undang-Undang Nomor 51 Tahun 2009 tentang Perubahan Kedua atas UndangUndang No. 5 Tahun 1986 tentang Peradilan Tata Usaha Negara. 